\title{
Mangelfulle språktester for utenlandske leger
}

\author{
Det er dårlig samsvar mellom det som kreves for å bestå en norsk språktest for utenlandske leger \\ og kravene til språkkompetanse i den virkelighet de skal jobbe i. Språkopplæringen for helsepersonell \\ fra utlandet må styrkes betydelig.
}

Den norskkompetansen som utenlandske leger og annet helsepersonell har fått før de ansettes ved norske sykehus, er ofte mangelfull. Rett nok kan mange vise papirer på bestått språkprøve i norsk, noe som indikerer et visst formelt nivå, men holder det i jobbsammenheng?

Dette handler om språkprøvenes validitet (1), for språkprøven og formålet med den må ses i en arbeidsrelatert og sosial kontekst $(2,3)$. Norskprøvene for innvandrere måler nok en viss basal språkkompetanse, kategorisering av språkkompetanse for øye bør man etterspørre validiteten i et tremåneders språkkurs for utenlandske leger og annet helsepersonell som ønsker å arbeide i Norge. Svaret kan bli bedrøvelig, for det er dårlig samsvar mellom en bestått generell norsk språktest og de språkkrav mange spesifikke arbeidsrelasjoner og mer perifere, men ikke uviktige sosiale relasjoner innebærer.

Dette kan kalles fremmedspråkopplæringens ironi - vi utstyrer utenlandske leger

\section{«Testene er en tvilsom indikator på den norskspråklige kompetansen utenlandske leger trenger for å lykkes godt i jobbrelaterte funksjoner»»}

et fundament å bygge videre på, men ikke mer enn det. Det er ikke overbevisende samsvar mellom «bestått» på den normerte språktesten og språkferdighetene som behøves i norsk helsevesen, i sykehusavdelingene, på vaktrommene, på morgenmøtene, i samtalene med leger og pleiere, i samtalene med pasienter, ved journalføring, i telefonsamtaler eller på e-post med pårørende $\mathrm{og}-\mathrm{ikke}$ minst $-\mathrm{i}$ eventuelle krisesituasjoner (4).

Som språkforsker kjenner jeg til dette fra flere hold, blant annet fra et opphold ved et utenlandsk språksenter der man arrangerte tremåneders norskkurs for utenlandske leger som skulle arbeide ved norske sykehus og andre helseinstitusjoner umiddelbart etterpå. Opplæringen var primært rettet mot en avsluttende, allmenn språktest. For språksenteret kan det ligge mer økonomiske enn språkfaglige interesser bak virksomheten - jo flere kandidater som kan kjøres gjennom og få sitt språkbevis, desto bedre butikk.

\section{Kvalitetssikring?}

Syke mennesker er ofte sårbare, og sårbare mennesker trenger i større grad enn friske forståelse, tillit og empati. Da er verbalspråket et viktig verktøy. Veldig viktig. Ulike yrkesområder har sine spesifikke språkdomener - et funksjonelt språk. Oljeog gassvirksomheten har mye engelsk i sitt språkfellesskap, bilverkstedene har sitt vokabular og selvsagt har leger og annet helsepersonell sitt. Med en slik funksjonell og annet helsepersonell med en språkkompetanse vi stilltiende betrakter som tilfredsstillende relevant (dvs. funksjonell) - uten kritisk å tenke gjennom eller kjenne til hvilken kompetanse som kreves på fagområdet (5). Så spørsmålet mitt går til norske helsemyndigheter: Er de standardiserte språktestene relevante og gode nok? Mitt svar er et ubetinget nei. Testene er en tvilsom indikator på den norskspråklige kompetansen utenlandske leger trenger for å lykkes godt i jobbrelaterte funksjoner.

Manglende språkkompetanse har også en annen, mer individrelatert side, som går på selvbilde, yrkesstolthet og identitet. To sykehusansatte utenlandske leger jeg snakket med, sa det slik: Det er en hard erfaring å komme fra situasjoner i hjemlandet som ener med sosial og faglig prestisje, anerkjennelse og trygg identitet til det å føle seg utilstrekkelig, tape trygghet og være annenrangs i Norge (6).

\section{Språklæring i kontekst}

Et tremåneders språkkurs med opplæring rettet mot å bestå en test er ikke godt nok. Minimum burde være kurs på et halvt år. Språkopplæringen bør organiseres i moduler - fra moduler for allmennspråk til spesifikt fagrettede moduler. Opplæringen bør legges til mottakerlandet og fortrinnsvis i fysisk nærhet til sykehus eller andre helseinstitusjoner. Dermed kan de språklærende hospitere i de faglige og sosiale miljøer de senere skal inn i. Da skaper man nærhet mellom språkopplæringen og de faglige og sosiokulturelle utfordringene den er ment å kvalifisere for. Bare slik kan man få en meningsfull språkopplæring som Helse-Norge kan være bekjent av.

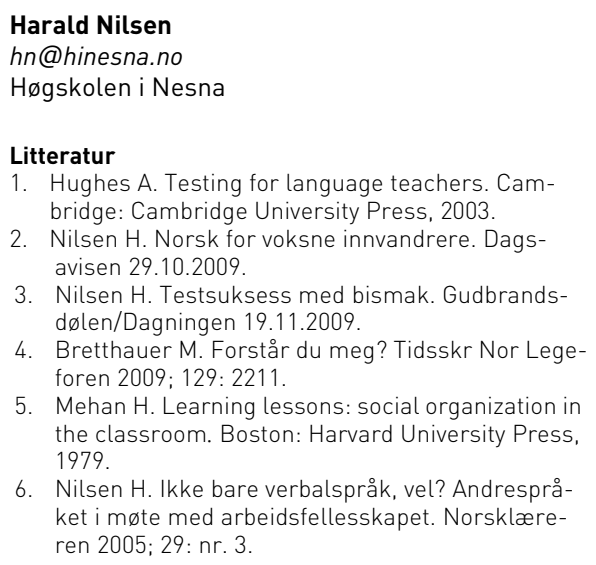

3. Nilsen H. Testsuksess med bismak. Gudbrandsdølen/Dagningen 19.11.2009.

4. Bretthauer M. Forstår du meg? Tidsskr Nor Legeforen 2009: 129: 2211

5. Mehan H. Learning lessons: social organization in the classroom. Boston: Harvard University Press, 1979.

6. Nilsen H. Ikke bare verbalspråk, vel? Andrespråket i møte med arbeidsfellesskapet. Norsklæreren 2005; 29: nr. 3.

Mottatt 19.10. 2010, første revisjon innsendt 23.11. 2010, godkjent 16.12. 2010. Medisinsk redaktør Petter Gjersvik. 